\title{
The Kosi Pralaya \\ Could the Catastrophe have been Averted? And What Next?
}

SB Pun

\begin{abstract}
The Kosi river breached its eastern embankment at Kushah in Nepal on August 18, 2008 causing havoc and misery to over 50,000 Nepalese and 2.5 million Indians in the state of Bihar. The affected people lost their homes, farmlands and livelihoods. Four months after the disaster, the affected people are still living in plastic tents in winter. Due to the impact of this catastrophe on the more industrialized and prosperous eastern Nepal, the overall effect on the country's economy has been severe. At the time of the breach, the river was actually below the level of normal discharge. There was no big flood in Kosi. This was not Nature's wrath but simply human failings. Bihar's Water Resources Minister, Vijender Yadav, admitted "The breach happened due to lackadaisical maintenance of the embankment', but laid the blame on the "previous government". With timely action such a disaster could have been averted.
\end{abstract}

Saif Uddin Soz, India's Union Minister for Water Resources, has already said publicly that "Kosi is in focus this time in particular...our main interest is flood control and irrigation," a statement that puts focus on implementation of the Sapta Kosi High Dam in Nepal. This dam will be built at a great social and environmental cost to the Nepalese people due to submergence of limited fertile valleys, displacement of large number of villagers and over $300 \mathrm{~km}$ of very large link canals from both banks of the dam (Kosi-Mechi and Kosi-Ghagra Links) to the Indian border. The attraction to Nepal is, of course, the 3,300 MW of power it will make available for export. The Sapta Kosi High Dam needs to wait until the vital 13-year pending issues of the "signed, sealed and done" 6,720 MW Pancheshwar Multipurpose Project on the Mahakali are finalized.

Key words: Kosi Catastrophe, Sapta Kosi high dam, Kosi barrage, flood, Nepal

\section{The Kosi Barrage: 'Reasonably Compensated'}

$\mathbf{T}$ The 1954 Kosi Agreement's 3,770 foot long 56 gated Kosi Barrage, 26 miles downstream of Chatara, with flood embankments of $146 \mathrm{~km}$ and $123 \mathrm{~km}$ respectively to irrigate 9,69,100 hectares $(6,12,500$ ha eastern canal and 3,56,60o ha western canal) in India was completed in 1962 with a 20 MW hydel station on the eastern canal in India (Dahal \& Adhikari 2005, Malla 1995). The revised 1966 Kosi Agreement stipulates that "all the lands and places as may be required for the proper execution" of the project "shall be leased by HMG to the Union for a period of 199 years from the date of signing of these amendments at an annual Nominal Rate." The December 19, 1966 letters of exchange between the two governments further stresses "that the Government of India will be reasonably compensated in case the Project properties are taken over by His Majesty's Government at the end of the lease period." India, after operating the Kosi Project for 199 years, deemed it necessary to still be "reasonably compensated" by Nepal. Present day Build, Own, Operate and Transfer (BOOT) projects like GMR's 300 MW Upper Karnali and Sutlej Nigam's 402 MW Arun III are handed over to Nepal without any compensation after 30 years of commercial operation. The developers, instead, are required to maintain the projects so that the specified generation capacity is ensured at the time of handing over the projects.

\section{The Kosi 'Pralaya' August 18, $2008^{1}$}

The Kosi 'Pralaya'-catastrophe-struck on August 18, 2008. As reported by Indian media (India Today, September 15, 2008). Bihar's Chief Engineer, E. Satyanarayana, stationed at Birpur (close to the Kosi Barrage), alerted the state government's Kosi Project Liaison Officer at Kathmandu on August 5 about the Kosi river mounting pressure on the Kusaha spurs, in Nepal about $12 \mathrm{~km}$ upstream from the barrage. With the situation worsening from August 9 to 16, Chief Engineer Satyanarayana sent frantic messages to 11 senior officials associated with flood management, warning them of imminent danger. Thus institutions within the Bihar government and also within the Union government (the Ganga Flood Control Commission in Patna and the Central Water Commission in Delhi) were informed. In fact, the August 17, 2008 bulletin of the Bihar Irrigation and Flood Control Department claimed that all embankments were safe! On August 18, however, the inevitable struck. ${ }^{2}$ The Kosi breached the Kusaha embankment as warned by Satyanarayana. ${ }^{3}$ The Kosi river was nowhere in its wild rampaging flooding state. At the time of breaching, the Kosi discharge was reportedly only 146,000 cusecs, when 'normal' flood discharges were in the vicinity of 350,000 cusecs with the recorded high at 900,000 cusecs. Note that it was actually below normal discharge when the breach and flood occurred.

On August 19, the Indian embassy at Kathmandu immediately launched a media onslaught to over 150 media destinations in Nepal (TV stations, FM radios, daily/weekly newspapers, and journalists) with the following press release:

The Embassy has seen news-reports in the media today about the breach in the Saptkosi embankment, severely affecting thousands of people in Nepal and India. The Indian technical team has been in Nepal for last several days to reinforce and strengthen the spurs and the embankment on the Saptkosi river in consultation with the local administration. However, 
despite repeated requests and pleas by the technical team for urgent local support in view of the gravity of the situation, the support from local administration had not been forthcoming. As a result, the work was frequently hindered, disrupted and delayed.

The concerns of the Indian technical team and the gravity of the situation were conveyed by the Embassy to the local administration and central authorities on 17th August and their cooperation and support was sought. At the same time, the Indian technical team was directed to carry out the work on day-and-night basis. The Indian technical team mobilized required resources and has remained in readiness to carry out the required work to strengthen the embankment but it was prevented from reaching the site. As a consequence, thousands of people in Nepal and India have been forced to suffer a calamity that could have been avoided.

The embassy's press release blamed Nepal squarely for the August 18 Kosi breach, stressing that the Indian technical team to reinforce the spurs and embankment were "in Nepal for last several days" and that the concerns of the team were conveyed to Nepal's "local administration and central authorities on 17th August". Many agree that the attempt to strengthen spurs from 17th August was both too feeble and far too late!

\section{The Costs}

Indian media also reported that Bihar's Chief Minister, Nitish Kumar, was informed of the Kosi breach only the next day, on August 19. Two days after the breach, on August 20, the Bihar Chief Minister made an aerial survey of the affected area. Visibly shaken by what he saw, Nitish Kumar called the Kosi disaster a "Pralaya"-a doomsday catastrophe and appealed to his people in the area to evacuate immediately! It is believed this Kosi Pralaya displaced over 50,000 Nepalese and 2.5 million Indians, though the human fatalities reportedly were less than a hundred.

India's Prime Minister, Man Mohan Singh, after an aerial survey, immediately sanctioned Indian Rs. 10 billion for Bihar. While Chief Minister Nitish Kumar sought Indian Rs 90 Billion, the Special Task Force constituted by the Indian Prime Minister assessed the flood destruction of Bihar as Indian Rs 250 Billion. In fact, S.C. Jha, chairman of the Special Task Force and also member of the Prime Minister's economic advisory council, advised that the rehabilitation and reconstruction work is beyond the State or Union governments' capability. He even suggested seeking assistance of the World Bank or the Asian Development Bank.

On the Nepal side, no such task force has been constituted. Instead, the country with such appeals as "May Lord Pashupatinath protect us" seems oblivious to the damages incurred in Nepal and the entire burden appears to have been thrust on the Sunsari Chief District Officer's shoulders. Nepal's media did report that the government would sanction Nepalese Rs 2.5 billion towards flood relief measures but was silent on who coughs up this amount. Indian ambassador, R.K. Sood, presented Prime Minister P.K. Dahal ('Prachanda') a check for Indian Rs 20 crore (Rs. 200 million) for flood relief, which "Nepal's No.1 English Daily", The Himalayan Times, had the arrogance to headline: "India's Bounty for Flood-hit" (October 17, 2008) .

\section{Who Foots the Bill?}

Politics (as usual) played its dirty game at the expense and miseries of the flood affected people. India's Union Minister of State for Water Resources, Jayprakash Yadav, accused his counterpart in Bihar, Vijender Yadav, of neglect in the Kosi barrage maintenance. Bihar's Vijender countered that the center failed to convene the crucial Indo-Nepal meeting on Kosi in 2004 and 2005. Vijender further charged that "The breach happened due to lackadaisical maintenance of the embankment by the previous government. That is why in the judicial probe we have included a reference point into the role of the previous state government in maintaining the embankments" (on the India Environment Portal). ${ }^{4}$

The central government and the Bihar state government are still fighting over who was responsible for the Kosi catastrophe, because this determines who ultimately 'foots the bill' for repairing the Kosi breach. In our own 'Bam Bhole's country' (i.e., the land of hashed Lord Shiva) no questions are asked as to who is responsible for the Kosi breach; who feeds and caters to the miseries of the 50,000 Nepalese $w$ ho (even after four months) are still housed under plastic sheets in winter; $w h o$ repairs the damaged roads and high voltage transmission lines; ${ }^{5}$ who rebuilds the ferry at Chatara; who foots all the extra transportation costs; etc. In fact, who foots the entire damage bill? So far the bills, for now cause of its own, are Nepal's fiat accompli.

\section{Could It Have Been Averted?}

When the Kosi Barrage Chief Engineer, E. Satyanarayan, alerted the concerned institutions of India on August 5, 2008, about the impending Kosi embankment breaching, no one bothered to listen to him. Strangely, the Patnabased Ganga Flood Control Commission and the Delhibased Central Water Commission failed to heed the Chief Engineer's warning. After the breach, the Bihar government awarded an Indian firm, Bashistha Construction, an Indian Rs.175 crore (Rs.1750 million) contract to return the Kosi river to its original track. One of the conditions of the Bihar government is that the contractor should equip itself with "300 tipper trucks, 40 excavators and 8 vibrator rollers" (Kathmandu Post, December 5, 2008). Many Nepalese believe that if only 50 tipper trucks, 10 excavators and perhaps a couple of bull dozers were availed after the Chief Engineer's alert of August 5th and had worked diligently 24 hours round the clock, the Kosi Catastrophe could have been averted.

Leaving aside the inadequacies of the Bihar government, why didn't the Indian Embassy in Kathmandu, the Central Water Commission in Delhi, and Patna's Ganga Flood Control Commission comprehend the enormity of the 


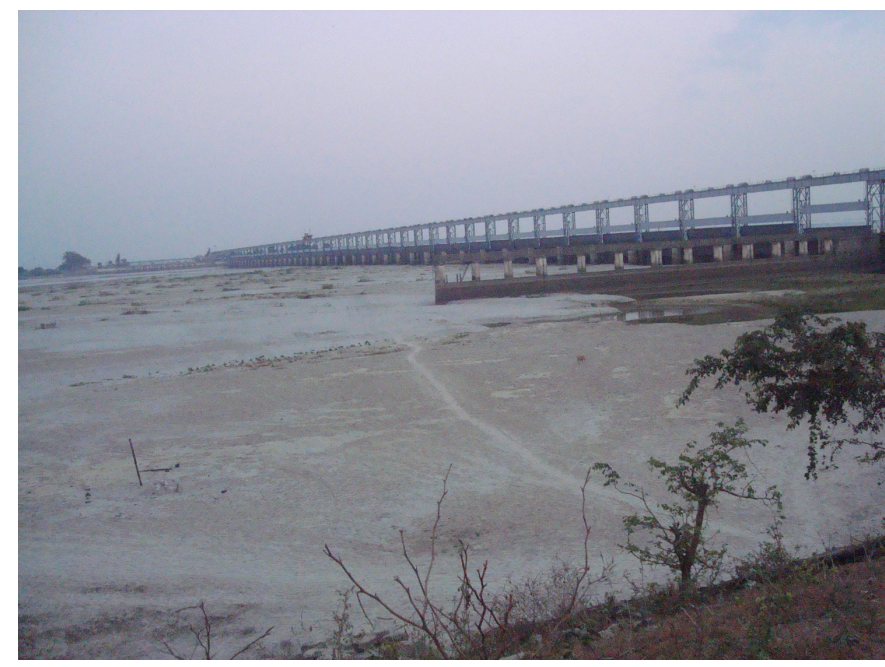

Dry Kosi Barrage

impending catastrophe that the Birpur Chief Engineer was warning about for two weeks? Surely, the nation that exploded the nuclear device and orbited a lunar module did not default on purpose?

Bihar's one-man judicial commission of ex-Chief Justice, R. Balia, may provide some answers. With due diligence, the colossal loss of property (but, thankfully, very few human lives) and the extreme miseries of winter that the displaced people of Nepal and India are facing could have been averted. The Kosi river, at 146,000 cusecs discharge at the time of the embankment breaching, was in no way in her normal flood fury. This was not nature's wrath but simply human failings!

\section{What Next?}

A plan to build a 783 foot high dam at Barahchhetra designed to moderate floods, and a 1,800 MW hydropower project and barrage at Chatara to irrigate 38.4 lakh (3.84 million) acres in India and Nepal, was prepared in June 1950 by India's Central Water and Power Commission; but it was shelved, because "the investment of large fund was not justified owing to insignificant flood moderation effect and low demand of power generated at the dam site... the comprehensive project...appeared to be unfeasible from the economic point of view" (GFCC, 1983). Instead, the Kosi Project, very much within Nepal with the barrage at Hanuman Nagar, was implemented through the 1954 IndoNepal Kosi Agreement. According to Verghese and Iyer (1993), "India was permitted to construct a barrage just within the Indian border, but with flood and afflux bunds... on Nepalese territory on lease for 199 years. Yet, at a faceto-face Reporters' Club Program in Kathmandu on May 26, 2001, the Indian Ambassador, Dev Mukherjee, maintained that "If the Indians had built the Kosi barrage a little downstream in Bihar, then Nepal's advantage would have been zero. And Indian irrigation instead of 0.95 million hectares would have been 0.935 million hectares" (Dahal \& Adhikari, 2005). ${ }^{6}$

With the life of the Kosi barrage ebbing away, India badly wanted to "reactivate" the Barahchhetra High Dam. At the

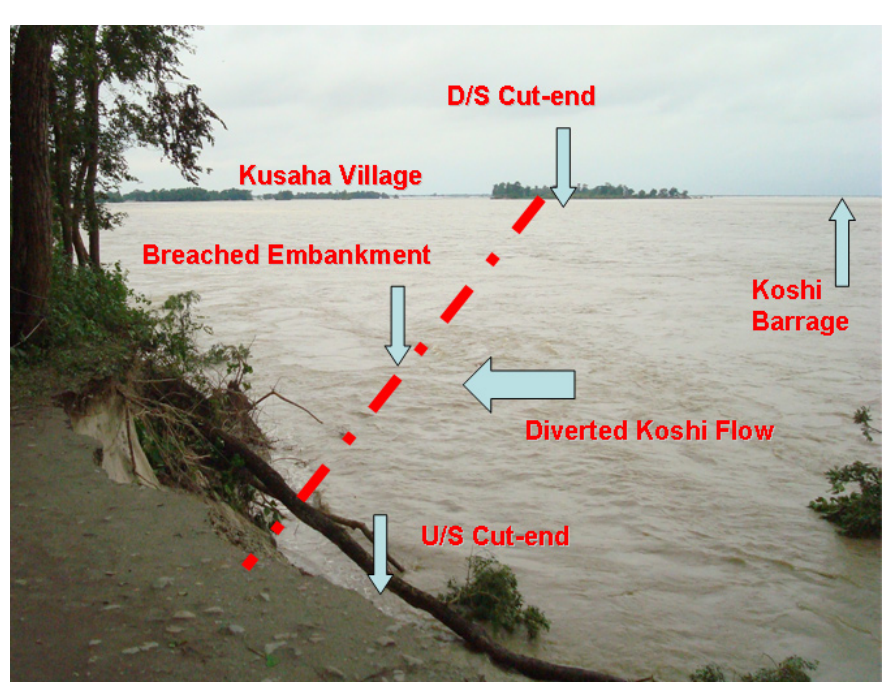

Kosi Flowing in Breached Portion

1991 secretary-level Indo-Nepal Sub-Commission on Water Resources meeting at New Delhi, India contended that the Kosi Barrage is a joint Indo-Nepal asset and that the barrage has "outlived its life and Kosi Multipurpose Project can only protect this asset." India further pointed out that the "utility of the project for flood control will be mainly confined within Nepal and India, and will not extend to Bangladesh."

Hence, India did not deem it "necessary to involve Bangladesh on the consideration of the Kosi Project." Due to Kosi's proximity to her, Bangladesh perceived the Kosi multipurpose project as a regional project to partner in. During Prime Minister G.P. Koirala's infamous visit of December 1991, India ensured that, among a host of IndoNepal water resources issues, the joint study of the Sapta Kosi High Dam Multipurpose Project be carried out expeditiously with a joint committee of experts to finalize 'the method of assessment of benefits'. With India gunning for the Sapta Kosi High Dam study, Prime Minister Sher Bahadur Deuba's government in 1996 was apparently ecstatic that India agreed to include the Sunkosi-Kamala Diversion also in the study. Thus emerged the India-funded Nepali Rs 46.8 crore (Rs. 468 million) study of the Sapta Kosi High Dam

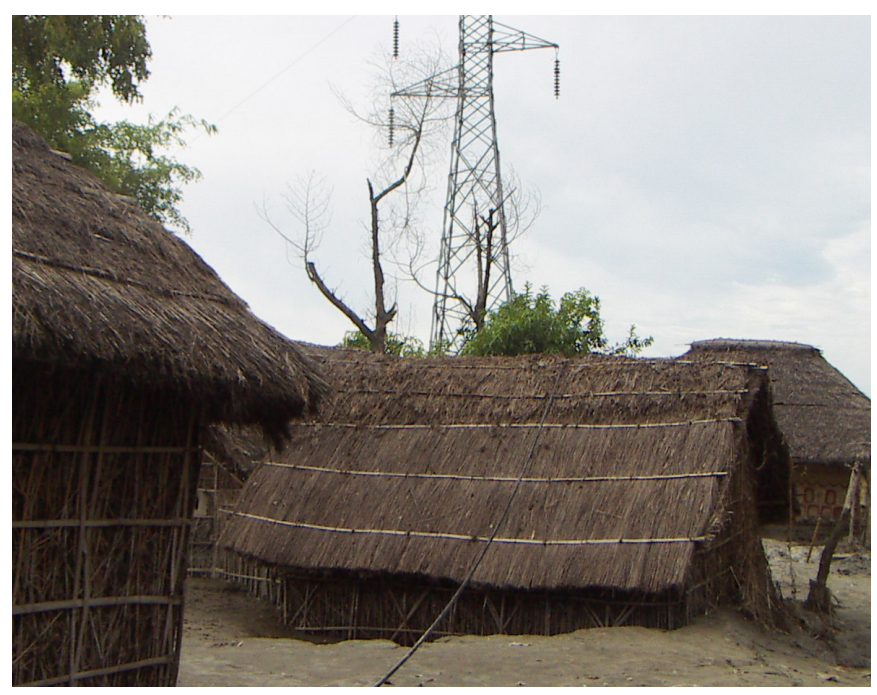

Damaged Transmission Line 
Multipurpose Project and Sun Kosi Storage cum Diversion Scheme (Dahal \& Adhikari, 2005) that has subsumed the studies of both the Kamala and Bagmati Multipurpose Projects as well. With seven project offices within Nepal but none in India, observers query on what basis Nepal will assess India's downstream irrigation and flood control benefits. India is "needlessly paranoid about classifying water resource data pertaining to the basin" (Verghese 1990), and is extremely shy to share her hydrological data with her neighbors.

The 269 meter (883 ft) gravity concrete dam $1.6 \mathrm{~km}$ upstream of Barahchhetra with a gross storage of 13.5 billion $\mathrm{m}^{3}$ (live 9.4 billion $\mathrm{m}^{3}$ ) will produce 17.6 billion units of energy from the 3,300 MW (300 MW on the canal) powerplant (GFCC, 1983). The dam is expected to submerge about $324 \mathrm{~km}^{2}$ of Nepal's fertile river valleys displacing over 75,00o people (Dixit 2062VS; 2005-06 AD). ${ }^{8}$ A barrage 8 km downstream will regulate the released water and two main canals, the Eastern and Western Chatara Canals, will takeoff from the barrage. The Eastern Chatara Canal will feed water to the existing Kosi Barrage at Hanuman Nagar for India's existing irrigational needs and Nepal's needs for the Sunsari, Morang and Saptari districts. This Eastern Chatara Canal will continue $100 \mathrm{~km}$ to hook with the Mechi River to become the Kosi-Mechi Link-one of the five Himalayan components in Nepal of India's 5,600 billion rupee River Linking Project. ${ }^{9}$ Similarly, the Western Chatara Canal is the far more ambitious second Himalayan component of the River Linking Project, the Kosi-Ghagra Link. This Western Chatara Canal, the Kosi-Ghagra Link, traverses over 200 $\mathrm{km}$ westwards through Nepal's principal granary basket to emerge into India near Birgunj. ${ }^{10,11}$

During the Maoist insurgency's closing phase, the study of the Saptakosi High Dam was badly affected, for the Maoists opposed it. With the Maoist-led tripartite government in power ${ }^{12}$ and the August 18 Kosi Catastrophe, India steamed full speed on tying up the loose ends of the Sapta Kosi High Dam with Nepal. ${ }^{13}$ On the very day S.C. Jha submitted his report on the Kosi flood damages in Bihar to Prime Minister Man Mohan Singh, India's Union Water Resources Minister, Saif Uddin Soz, was having a 'one to one' meeting with his Nepalese counterpart, Bishnu Prasad Poudel. ${ }^{14}$ While the two agreed to expedite the Sapta Kosi High Dam feasibility study, Indian media has reported that Prime Minister Pushpa Kamal Dahal ('Prachanda') met Bihar's Chief Minister, Nitish Kumar, over lunch and "affirmed his intention of building a high dam on the Kosi." 15 Union Minister, Saif Uddin Soz, in his interview with the BBC Nepali Service, said "We have already taken decisions and we have to implement them honestly.....Kosi is in focus this time in particular....Our chart of activities is well drawn, there is no difficulty.... Our main interest is flood control and irrigation. Those are our first and second priority. If we get hydroelectricity as a byproduct, it will be a bonus for us" (Nepali Times, September 19-20, 2008).

Nepalese leaders' 'one to one' meetings with Indian leaders generally come out in the public very belatedly, after those leaders no longer wield power. Past experiences indicate that such meetings have generally ended to Nepal's disadvantage. Though it is not known what decisions were taken behind the scene during the two governments' talks, Kosi is very much in focus this time with flood control and irrigation as India's first and second priority. For the past five decades, India very shrewdly camouflaged her irrigation and flood control benefits, be it in the study of Karnali Chisapani or the Pancheshwar Multipurpose Projects. India aimed to derive these benefits through Nepal's default (Subba, 2002). As evidenced by the recent Kosi catastrophe, India has unwittingly become a victim of her own machinationsby not agreeing to flood control and irrigation benefits in the studies of previous multipurpose projects!

\section{Conclusions}

The Kosi High Dam has now become the top priority for the Ganga Flood Control Commission, for the Central Water Commission and for the Governments of Bihar and India. The dam not only mitigates the flood but also stores valuable freshwater for India's ambitious Kosi-Mechi and KosiGhagra links. Though this dam is expected to capture about $78 \%$ of the Kosi's flows, Dr. Sudhirendar Sharma of the Delhibased Ecological Foundation believes that the remaining 22\%-“a dangerous portion"-will still flow. According to Dinesh Kumar Mishra, former Bihar engineer who has studied the Kosi since 1984, the Majumdar Committee had recommended against a high dam on the Kosi in Nepal due to high seismicity in the region. The 1934 earthquake measuring 8.3 on the Richter scale had caused massive destruction both in Bihar and Nepal. Mishra warned that "A breach in the dam could spell disaster of unprecedented scale for Bihar"; and for Nepal, as well. There are others who advocate that the Kosi be left to itself; that is, leave it flowing as it is in its present breached course.

While the pros and cons of the Sapta Kosi High Dam are being debated in India, no such serious debates have taken place in Nepal itself. ${ }^{16}$ While the media reported extensively on the Kosi embankment breaching, they have all ebbed away very quickly, and public memory is extremely short. The displacement of 75,000 Nepalese for the benefit of people across the border, the submergence of $324 \mathrm{~km}^{2}$ of Nepalese flora, fauna and fertile lands for perpetuity, the straddling of massive Eastern Chatara (Kosi-Mechi link) and Western Chatara (Kosi-Ghagra link) Canals totaling over $300 \mathrm{~km}$ in Nepal's food basket, and the consequent water logging and salination appear to have been all subsumed by the 3,300 MW carrot and the charms of the Tehri-like dam and Bhutan Model! ${ }^{17}$

Nepal needs to ask why India vacillated on the 10,800 MW Karnali Chisapani Multipurpose Project that the World Bank was ready to finance in the 1980s. Nepal needs to consider why the 'signed, sealed and done' 6,720 MW Pancheshwar Project has failed to move for the last 13 years. India does not agree with Pancheshwar's irrigation and flood control benefit assessment of $25 \%$ and $1 \%$. On power benefit assessment, though over $66 \%$ of India's existing plants are 
thermal based, India has her own interpretations of the 'alternatives' available. Nepal insists that "savings in cost to the beneficiaries as compared with the relevant alternatives and avoided cost of alternatives" are the same.$^{18}$ India insists on the right to existing consumptive uses extending beyond $160 \mathrm{~km}$ of the Sarada Barrage into the Lower Sarada Sahayak command area. While the sill levels of the Nepal and India intakes at the British-India made Sarada Barrage are at the same levels, Republic India has conveniently constructed Nepal's sill level at Tanakpur barrage $\mathbf{1 1 . 6}$ feet above her own. ${ }^{19}$ For the last 65 years India has failed to return the 36.6 acres of land due from Sarada barrage time. ${ }^{20}$ India insists the Mahakali originates from the Kalapani Tal (lake), thus occupying about 37,840 hectares of Nepalese territory (Shrestha, 2003). ${ }^{21,22}$

It appears that while the Devas part away with the 'amrit and gems', Nilkantha's (blue throated Lord Shiva) Nepal has to make do with the 'bikh' (poison). Observers, therefore, believe that the finalization of Detailed Project Report on the Saptakosi High Dam can afford to wait till these vital issues on the Mahakali are finalized once and for all.

Santa Bahadur Pun is a former Managing Director of Nepal Electricity Authority and former Officer on Special Duty at the Ministry of Water Resources, Government of Nepal.

Corresponding address: santapun@ntc.net.np

\section{Notes}

1 Pralaya was the exact word coined by Bihar's Chief Minister, Nitish Kumar, after making an aerial survey of the affected areas on August 20, 2008. Catastrophe does not convey the same sense as 'pralaya' which actually means doomsday, the end of the world.

2 This 'inevitable' was coined by Dinesh Kumar Mishra, a Bihar engineer. Mishra is author of the book 'Badh Se Trasht-Sinchai Se Pasht' (Fear from floods and fed up with Irrigation) 1990.

3 The travesty of the Chief Engineer: On August 17, E. Satyanarayana was demoted and transferred from Birpur "seemingly because of an earlier enquiry unrelated to the floods", according to India Today (September 15, 2008).

4 www.indiaenvironmentportal.org.in/content/canbihar-avert-another-kosi-disaster.

Reference to the "previous government" in this statement on the Internet means the government of the then Chief Minister Laloo Yadav who is now the powerful Union Railway Minister in the present government. Regarding the "judicial probe" mentioned, the Bihar government appointed Rajesh Balia, former Chief Justice of Patna High Court, to conduct a one-man investigation into the breach of the Kosi embankment according to The Bihar Times (Patna): September 11, 2008).

5 The Nepal Electricity Authority (NEA) has tendered out the work on the damaged $132 \mathrm{kV}$ transmission lines "to be billed to India", apparently without India's concurrence (National Electricity Crisis Mitigation Action plan, Poush 10, 2065/December 25, 2008).

6 The Kosi Barrage actually irrigates 969,100 ha in India and 11,300 ha through gravity flow and 13,800 ha through costly lift pumping in Nepal.

7 Prime Minister G.P. Koirala's visit was "infamous" because it was during that trip that he signed away 11.9 ha of Nepalese land (9 ha under submergence and 2.9 ha unsubmerged) for "10 MW of free energy" through what is called the "Tanakpur MOU" (Memorandum of Understanding).

8 The amount expected to be submerged (about $324 \mathrm{~km}^{2}$ of Nepal's fertile river valleys) includes $196 \mathrm{~km}^{2}$ agricultural, $78 \mathrm{~km}^{2}$ forest and $50 \mathrm{~km}^{2}$ other lands. The backwater of the Kosi High Dam reaches out as far back as the Tumlingtar airfield.

9 India's five River Linking Projects in Nepal are: (1) KosiMechi Link, (2) Kosi-Ghagra (Karnali) Link, (3) GandakGanga Link, (4) Ghagra (Karnali)-Jamuna Link, and (5) Sarada (Mahakali)-Yamuna Link. Among the five, the KosiGhagra (Karnali) link is the most ambitious, having huge social and environmental impacts on Nepal.

10 The Western Chatara Canal, the Kosi-Ghagra Link traverses eight districts in the Nepal Terai: Udaypur, Saptari, Siraha, Dhanusha, Mahottari, Sarlahi, Rautahat and Bara.

11 Feasibility reports of the 16 Peninsular Links are available on the Government of India's website (www.nwda.gov.in) for public scrutiny but those of the Himalayan Links are not available because the data are classified as confidential.

12 CPN-Maoists, CPN-UML and Forum, with CPNUML holding the Ministry of Water Resources portfolio. (CPN=Community Party of Nepal; UML=United MarxistLeninists.)

13 Some interpret this as a god-send for India's water bureaucracy to push the Sapta Kosi High Dam Multipurpose Project to its logical conclusion.

14 Minister Poudel was in the entourage of Prime Minister Pushpa Kamal Dahal ('Prachanda') who was in New Delhi at India's invitation.

15 www.indiaenvironmentportal.org.in/content/canbihar-avert-another-kosi-disaster.

16 Nepal's Water Resources Ministry has clarified that only studies are being undertaken on the Sapta Kosi High Dam and Sun Kosi-Kamala Storage cum Diversion Scheme. No construction work is being undertaken. The Ministry, however, goes on to add that compensation, rehabilitation and resettlement will be on an equitable and social justice basis (Kantipur, Poush 8, 2065/December 23, 2008). Such a premature pronouncement by the Ministry foretells its intentions. Strangely, the Sapta Kosi High Dam has already found a place of top urgency in the present government's 35 -Point program to eliminate load shedding in Nepal!

17 "Tehri-like projects likely for Nepal" was a front 
page headline in The Himalayan Times (Kathmandu) of December 18, 2008. Tehri is a district in the north Indian Himalayas west of Nepal.

18 Reply of Nepal's Water Resources Minister, Pashupati S.J.B. Rana, to Member of Parliament, K.P. Sharma Oli, on 2053/5/6 (August 22, 1996) in a Ministry of Water Resources publication dated Kartik 29, 2053 (November 14, 1996).

19 The sill levels of Nepal and India intake canals at Sarada/ Banbasa Barrage are at the same level, 220.52 meter above mean sea level (amsl); but, at the Tanakpur Barrage while the sill level of Nepal's intake canal is at 245 meter amsl, India's sill level is at 241.5 meter amsl; i.e., 3.5 meter (11.6 feet) lower than that of Nepal. Kathmandu's daily Kantipur (Poush 4, 2065/December 19, 2008) reports that Nepal has started construction work on the Third Phase Mahakali Irrigation Project that originates from the Tanakpur Barrage. It is not clear what has become of the sill level dispute.

20 On this issue, Ambassador K.V. Rajan, in his interview with Nepal's RSS new service on September 11, 1996, replied "It seems a matter that goes back to 1920 before India became independent. It seems as if after actual land... This is a very small, very technical matter... to the total satisfaction of Nepal in the very near future."

21 Nepal's Water Resources Minister, Pashupati S.J.B. Rana, in his written reply of 2053/5/11 (August 27, 1996) to Member of Parliament K.P. Sharma Oli, the CPN-UML party's coordinator of the Mahakali Treaty Study Task Team, has maintained that the Government of Nepal is crystal clear that Kalapani Tal is not the origin of Kali river (as noted in a publication of the Water Resources Ministry, Government of Nepal, Kartik 29, 2053/November 14, 1996).

22 In a comparable case internationally, in 1993 Nigeria sent security forces to occupy the disputed $1,000 \mathrm{~km}^{2}$ Bakassi Peninsula said to be rich in oil and gas. In 1994 Cameroon filed the case at The Hague's International Court of Justice, which rules in 2002 in Cameroon's favor. In August 2008 Nigeria returned the territory "in the interest of African brotherhood and good neighbourliness.. however painful it may be."

23 Nilkantha/Shankar, with his throat poisoned blue, strikes the mountain with his Trishul to quench his thirst for water, thus forming the Gosaikunda lake (in Rasuwa District), the origin of the Trishuli river.

\section{References}

Dahal, M.K. \& D. Adhikari, 2005, Partnership in Economic Development, An Enquiry into the Indian Aid Policy to Nepal, Kathmandu: BP Koirala India Nepal Foundation, Embassy of India.

Malla, S.K., 1995, Water Resources Development Nepalese Perspectives, New Delhi: Konark Publishers Pvt. Ltd.

Mishra, Dinesh Kumar, 1990, Badh Se Trasht-Sinchai Se Pasht (Fear from floods and fed up with Irrigation), Patna: Samta Prakashan.

GFCC, 1983, Comprehensive Plan of Flood Control for the Kosi Sub-Basin, New Delhi: Ganga Flood Control Commission, Ministry of Irrigation, Government of India.

Verghese, B.G. \& R.R. Iyer, 1993, Harnessing the Eastern Himalayan Rivers, New Delhi: Kanark Publishers Pvt. Ltd.

Verghese, B.G., 1990, Waters of Hope, New Delhi: Oxford \& IBH Publishing Co.

Dixit, Ajaya, 2062 VS (2005-06 AD), Questions Raised by High Dams, Mulyankan, Chaitra 2062:

Mirza, M.M.Q. \& Q.K. Ahmad, 2008, Interlinking of Rivers in India: Issues and Concerns, London: Taylor \& Francis Group.

Subba, Bhim, 2002, Water, Nepal and India in State of Nepal, edited by K.M. Dixit KM \& S. Ramachandran, Kathmandu: Himal Books.

Shrestha, G.N., 2003, Border Management of Nepal, Kathmandu: Bhumichitra Co. Pvt. Ltd. 